\title{
Predicting muslim consumers' purchase intention of previously retracted and recertified halal products
}

\begin{abstract}
The purpose of this paper is to test the influence of attitude, subjective norms, brand image and halal knowledge on the purchase intention of previously retracted and recertified Halal products among Muslim consumers. This study used self-administered questionnaires that were distributed using convenience sampling. A total of 200 questionnaires were collected from respondents in Kelantan, Negeri Sembilan, Selangor and Perak. The findings of the study revealed that attitude, subjective norms and brand image significantly predict Muslim consumers' purchase intention of previously retracted and recertified Halal products. However, halal knowledge was found to be insignificant towards purchase intention. The findings are primarily beneficial for the marketers of halal products by offering an insight into the intention of consumers to purchase products that had previously been retracted off their Halal certification.
\end{abstract}

Keyword: Purchase intention; Halal recertification; Retracted Halal products 